\title{
III. THE PHILOSOPHY OF THE PARTICULAR AND THE UNIVERSALITY OF THE CITY Socrates' Education of Euthyphro
}

\author{
ARLENE W. SAXONHOUSE
}

University of Michigan

\begin{abstract}
A
CENTRAL TENSION IN POLITICAL LIFE is the conflict between the universal and the particular. While the language may seem to turn us to the metaphysical speculations of idealist philosophy, the problem is grounded in the very task of politics as a realm that must create a unity of diverse citizens. The citizen becomes one whose individuality must recede before the abstract definitions of the city. As the Eleatic Stranger notes in Plato's Statesman, best would be a world in which guardians could be set over each individual member of the community; or we might think here as well of Rousseau's Emile and his personal tutor. But such particularistic care is beyond the resources of the polity, and legal abstraction from the particular becomes the currency of the political life of the community. Plato's Eleatic Stranger and Rousseau must both turn to the abstractions of the laws, laws that are to apply universally to citizens of any given community despite those citizens' particularity.

In contrast to the abstraction of the city's laws stands the family, that realm in which we find attention to the particular, be it child, father, wife

AUTHOR'S NOTE: This article is an abbreviated version of a paper presented at the 1985 annual meetings of the American Political Science Association in New Orleans and before the Study Group in Law and Culture at the University of Michigan. I acknowledge the helpful comments received on those occasions as well as those of the anonymous reviewer for this journal.
\end{abstract}

POLITICAL THEORY, Vol. 16 No. 2, May 1988 281-299

(1988 Sage Publications, Inc. 
or servant. The opposition between the city and the family captures the opposition between the universal and the particular and gives rise to the tensions that govern our lives as both unique individuals and members of a larger community that must abstract from our uniqueness. In this article I explore these issues and tensions by turning to the writings of perhaps the most profound exponent of the relationships between the universal and the particular. Specifically, I intend to explore the place of filial and paternal (i.e., particularistic) ties within the universally oriented world of the city by looking at the Euthyphro, the dialogue in which Socrates confronts a young man "wise in the ways of the gods" who chooses to bring his father before the laws of the city on the charge of murder. We find in this dialogue (as well as in the Apology to which I shall refer briefly at the end of this article) a Socrates eager to introduce into political life the sort of care present in the family; however, such care for the particular does come into conflict with polity's need for impartiality. The peculiar case of Euthyphro subjects this tension between the concerns of the family and the reasonable need of the city for unbiased judgments to Socratic investigation and thus serves as a preface to Socrates' relation to the city in the Apology.

\title{
THE PHILOSOPHER, THE CITY, AND THE ABSTRACTION FROM THE PARTICULAR
}

\begin{abstract}
For this is the saying of Homer: I have not been born "from oak or from stone" but from human beings.
\end{abstract}

Socrates cites this passage from Homer near the end of his speech before the city (Apology, 34d). The Homeric quotation prepares us for Socrates' use of the overused oratorical trick of introducing a subject to the consciousness of one's audience by announcing that one will not discuss it. Thus Socrates introduces, at the same time he undermines, the philosopher's relationship to the family. He thereby raises, not only the problem of what can be and what is the relation of the philosopher to the family, but also whether a devotion to the family denies an attachment to the city and/or the god he claims to serve in his pursuit of the philosophic life.

Certainly other portrayals of Socrates suggest a man if not hostile to, at least unconcerned with, the demands of family ties on the individual who sees himself as part of a larger unity - be it the world of philosophy or of politics. In Republic V, for example, Socrates destroys the families 
and denies any opportunity to feel bonds with any particular individual. Children, mates, parents are all universalized and everything is done to preclude calculations that might lead to a knowledge of such particularistic ties. It is precisely the establishment of individual households in Book VIII that marks the decline of regimes. In Aristophanes's Clouds, Strepsiades burns down Socrates' school, for he sees the phronisterion (think tank) as threatening his family. Preferring to preserve that which is his own (his wife and his son), Strepsiades destroys the sophist who makes men reason so abstractly that they can justify the beating of one's parents and condone incest between brother and sister. ${ }^{1}$ And as Socrates says of himself in the Apology: "On account of this lack of leisure time [as he goes around showing people their ignorance], there is no leisure for me to handle any of the affairs of the city ... nor of my household, but I am always in poverty 10,000 times on account of my service to the god." (23b-c) All these examples suggest a Socrates focused on the abstract world of philosophy and scorning the particularistic family with its internal bonding.

And yet, despite the rhetorical claim to remove the family from his speech before the city, running through the Platonic dialogues that capture the story of Socrates' last days, his trial and his death, is the acknowledgement that he was not "born of oak or stone" and that indeed men are bound through physical, emotional, and religious ties to their families. ${ }^{2}$ Plato seems to suggest through these dialogues in the person of Socrates that the philosopher is not the source of abstraction that moves the individual away from particularistic ties, but that the polity itself is responsible for these abstractions. The philosopher Socrates is concerned with care of the particular exemplified by relations within the family. ${ }^{3}$

Socrates' concern with the particular, a point I intend to illustrate through an analysis of the Euthyphro, thus sets him at odds with the development in Athens of the democratic polity that, with its focus on equality before the laws, aimed at a citizenry of equals bound to the city by their uniformity rather than their individuality. To achieve the unity of the city, the traditional bonds to the family needed to be fractured and the individual released from those ties. Aristotle, describing Cleisthenes' reforms of 508-507 B.C., reforms considered by the Athenians to be the beginning of their peculiar form of political regime, notes: "Cleisthenes first distributed all into ten tribes instead of four, wishing to mix them up so that more of the citizens might have a share in the politeia. From which it was said: 'Do not judge by tribe.'.. And he made those living in each deme fellow demesmen of one another, so that they were not called 
by their father's name . . but named according to their deme."4 J-P Vernant has suggested that "with Cleisthenes, the egalitarian ideal was directly linked to political reality ... it inspired a reshaping of institutions. The world of social relations thus formed a coherent system, governed by numerical relations and correspondences that permitted the citizens to declare themselves 'the same,' to enter into relations of mutual equality, symmetry and reciprocity." While the breakdown of the old tribes and the institution of the new demes became the grounds for the identity of the citizens, the institution of the lot for all except certain military offices and financial appointments ${ }^{6}$ led to a society "in which each citizen, because he was like all the others, would have to cover the entire circuit as time went round, successively occupying and surrendering each of the symmetrical positions that made up civic space. '" The polity transforms any one individual, set in a particular series of relationships with particular traits, into a member of a group of individuals abstracted from those ties and traits.

Accompanying this new vision of social and political relations expressed in the democratic reforms of Athens, we see a new picture of the individual removed from his past; thus, for example, Orestes stands, almost irrelevant, in Aeschylus' optimistic Oresteia, shorn of all individuality, as others debate abstract principles of maternity and birth, ignoring the particularity of the son who has murdered his mother. Justice has moved from the web of familial particularity of the father killing the daughter, the wife the husband, the son the mother, to the abstract city that tried Orestes' case before a group of strangers chosen by lot, that is, by the mere fact that they were citizens and had no particular relationship to Orestes or to the individuals who were murdered. A focus on the family forces the individual away from such abstractions of the polity toward particular relationships and individual traits. It is for this that the Furies as guardians of household justice fight-and lose. ${ }^{8}$ While I certainly do not want to make an analogy between the Furies and Socrates, I do want to suggest that we can see both as resisting the city's thrust toward abstractions that deny the origins of human beings in the bodies of others and the bonds of care that those origins create.

The issues expressed above have resurfaced recently in some of the contemporary literature dealing with developmental psychology and the psychology of mothering, particularly in the writings of such authors as Carol Gilligan and Nancy Chodorow. ${ }^{9}$ But in these discussions gender has been introduced as the relevant variable, and it has been suggested that there is a dichotomy between a male focus on abstraction 
and universal rights and a female concern with a "web of relationships" that arises from an acknowledgement of individuals' traits and past associations. In the person of the Platonic Socrates, however, we find the transcendence of such a gender dichotomy, and more important, an understanding of the complexity of the relationship between particular and universal or web and hierarchy in the structure of any political community. ${ }^{10}$ Socrates, the hermaphrodite in so many contexts in Plato's dialogues, opposes the city that tries to abstract from the particularistic, familial ties of the individual. The web of relationships perspective is not peculiarly feminine but encompassed in both paternal care and filial piety-dependent for the Greeks on the physical bonds arising from the processes of procreation as suggested in the quotation that introduced this section. Socrates draws forth for us the problematic interrelationship between a particular being with particular associations and the city that demands an abstraction from the particular. In part, this article is an attempt to move away from the vision of abstract Socratic rationalism to a Socrates fundamentally aware of the web of relationships and the critical role of particular individuals. He has this understanding despite his status as male, citizen, and philosopher. In his case this becomes a critique of the political realm, which through its laws and the hardly unreasonable impartial application of those laws, moves its citizens toward abstractions. We come to understand this critique through Socrates' education of Euthyphro- to which I now turn.

\section{THE EDUCATION OF EUTHYPRHO}

Most studies of Plato's Euthyphro categorize the dialogue as an early, aporetic work, one that asks what a particular virtue is, be it courage, moderation, piety, and then fails to answer, at least directly, the question posed. The Euthyphro is seen as particularly interesting because, though supposedly written early in Plato's career, we find in it glimmers of the "later" theory of the forms. " The dialogue thus becomes interesting in these interpretations because of subsequent developments rather than on its own. I wish to take seriously the dialogue on its own and to show that rather than foreshadowing the theory of forms or ideas, the dialogue raises questions about the political implications of a philosophic drive toward abstraction such as that entailed in the theory of the forms.

The two characters of the Euthyphro meet on the steps of the Stoa 
Basileus in 399 B.C. It was the function of the archon basileus, the magistrate located at the Stoa Basileus, to deal with legal cases having to do with religion, including homicide cases, by assigning them to one of the particular courts charged with handling cases of impiety or of homicide. For instance, the archon basileus must determine whether a case is to be heard in the Palladium, the appropriate setting for cases of unintentional homicide "and anyone who kills a slave or a metic,"12 or at the Areopagus for cases of deliberate homicide or wounding. ${ }^{13}$ The setting of this dialogue at the Stoa Basileus has further significance, though. It was here that the laws of the city stood inscribed on the stone tablets, the stele, for all to see in their physical manifestation. In a movement foreshadowing Justinian sixth-century codification of Roman law, the Athenians appointed inscribers in 410 B.C., men who were responsible for reinscribing the law of Solon and Drakon. Any law not so inscribed lost its force; the validity of the laws depended on their physical presence at the Stoa Basileus. ${ }^{14}$ Thus, as Euthyphro and Socrates discuss the meaning of piety, they are surrounded by the laws of the city, laws that are physically present and visible on the stele around them. The democracy that had asserted the equality of all before the laws of the city stands before them.

Let us turn now specifically to the dialogue. We, as readers of Plato, know why Socrates is present on the steps of the Stoa Basileus. He has been accused of corrupting the young and introducing new gods into the city. Euthyphro, however, does not know the reason for Socrates' presence. Plato would have us believe that the prosecution of Socrates was a major political event of the time. Euthyphro is somewhat befuddled, removed from the day-to-day life of the city, unaware of the events that have brought Socrates to porch of justice. Like Socrates he seems a stranger in the political world of Athens (cf. Apology, 17d).

In the first interchange, Euthyphro assumes that Socrates does not have a diké, a private case, "as I do." Socrates responds: "A graphé the Athenians call it," indicating that he was there for a public crime, a crime that threatens the community at large. Such a case can be brought by any citizen supposedly concerned with the welfare of the whole community. Euthyphro, in contrast, arrives as a private citizen bringing a suit against another private individual (who, as we later discover, happens to be his father). A dike must be brought by those affected by the crime, those who use the institutions of the city to resolve private conflicts as Apollo and the Furies do in the Eumenides. Graphae are 
brought by those who claim to care to preserve the institutions themselves against those who threaten them.

Euthyphro has come to prosecute his father for murder in a case so ambiguous as to make law school moot court cases look simple, but the major question that must introduce a consideration of Euthyphro's case is: What is the incentive to bring this case to trial? What motivates the young man to go against his father with far less reason than Orestes has to act against his mother or her Furies against him? Socrates, who was portrayed in the Clouds as justifying the beating of one's father, is shocked (4a-b, c). Euthyphro's relatives are also shocked and angry at him (4d). No one can understand Euthyphro's actions except Euthyphro himself. As he himself admits, by bringing "this man" to trial he "seems to be mad, mainesthai" (4a).

To understand the full extent of the difficulty with Euthyphro's decision to prosecute his father, we must review what is known about homicide law in the Athens of this time. ${ }^{15}$ The primary source for this is the inscription of Drakon's homicide law. The problem with homicide law is unique, since for all other private cases the one harmed was the one to bring suit against the accused. Obviously this is impossible in the case of homicide. The question then is who is to bring the case of homicide to court on behalf of the deceased. According to Drakon's law engraved on a stele and placed at the Stoa Basileus around 408-409 B.C.: "The basileis are to adjudge responsible for homicide either the actual killer or the planner; and the Ephetai are to judge the case. If there is a father or brother or sons, pardon is to be agreed to by all, or the one who opposes it is to prevail. ... A proclamation is to be made against the killer in the agora by the victim's relatives as far as the degree of cousin's son and cousin."16 The question that scholars have debated is whether one was required to prosecute. One scholar suggests that a relative might feel an obligation but that there was no sanction should one not bring a case. ${ }^{17}$ Others, not quite knowing what to do with the Euthyphro but referring to a case described by Demosthenes, argue that no one but a relative could bring a case. ${ }^{18}$ Euthyphro acts neither as kin of the murdered man nor as master of a slave. In no sense can we assume that he is legally required to act. The man who has died, bound and thrown into a ditch, is explicitly a pelates, a dependent one or a hired hand of Euthyphro's father. We are not informed as to whether this man had a living father or any relations, even so far as a cousin's son.

When Euthyphro informs Socrates that it is his father that he intends to prosecute, Socrates assumes: "It must have been for the sake of a relative, but not a stranger." Euthyphro's response is significant: " $O$ 
Socrates, that is laughable, that you think there is any difference whether the dead man is a relative or not," (4b) even though the law says that there is a difference. For Euthyphro the only question is whether "the killer killed in justice (en diké) or not, and if with justice, let him be, but if not, to bring a case against him even if the killer shares one's hearth and one's table" (4b-c). Euthyphro desires a concept of righteousness that is absolute and can remove him from the complexities of familial ties. The murder was either just or not; the nature of the relationship to the murderer or murdered man is irrelevant. Euthyphro wants universal prescriptions without complexity. For this, he turns to the abstract institutions of the city-to the public realm for the case that traditionally was handled as a private crime. ${ }^{19} \mathrm{He}$ has an abstract notion of diké, justice, right and wrong that moves away from any particularity of relationships. The puzzle set up by Euthyphro is the contradiction between justice for which he turns to the city and piety that is demanded by the family. ${ }^{20}$

Euthyphro desires a concept of righteousness that removes him from the complexities of familial ties; to find them, he searches first in the laws of the city-indeed giving them a greater universality than they may have. Thus he must expand his abstract notion beyond the city to the gods. Though the preserved provisions of Drakon's law are "entirely secular and contain no indication of any religious origin or purpose," 1 Euthyphro perceives his actions as "pious." "The pollution (miasma) is if you knowingly associate with such a man and do not purify him and yourself by prosecuting him" $(4 \mathrm{c})$. The purification Euthyphro seeks is to come from the laws of the city, not from the religion of the family. But his relations, including, not surprisingly, his father, are angry at him, saying that it is not holy for a son to go against his father. Euthyphro's reaction is: "They don't understand (kakōs eidotes) how the divine thinks concerning the holy and the unholy" (4e). Yet, despite his own professed antipathy for the masses, Euthyphro finds this understanding in the laws of the city and what the many in fact do say about their gods (5e-6a). We should note, however, that it was Euthyphro's father who had sent to the exegetes, the religious interpreters, to inquire as to what he should do with the murderer and that the murderer died while the father waited for the answer. ${ }^{22} \mathrm{He}$ saw the complexity of a case in which a hired hand unintentionally kills a slave. Euthyphro assumes that the still more complex case with which he is confronted is simple.

Euthyphro longs for a simplicity of moral precepts that can include all: family members, the city and the gods. Distinctions of relations to each must be transcended by those "who know well" the nature of 
things. He, in seeing the world as simple, turns to the laws, the abstract institutions of the city that with the creation of democracy have moved men away from being enmeshed in the family to equal individuals. Socrates draws out Euthyphro's desire for simplicity, plays up to him in this way in order to make him fall. Thus, Socrates marvels that Euthyphro knows these things so clearly (akribōs) that he has no fear that by prosecuting his father he may be doing something that is unholy. Euthyphro assures Socrates that he, Euthyphro, would be worth very little, hardly different from the many, if he did not know all such things clearly (akribōs). He, Euthyphro, as special, can see the unity of all, whereas others can only see what is complicated. Citizens, though they depend on the universality of their principles, do not always recognize that need.

When Euthyphro is then asked by Socrates to define the idea of the holy, he offers Socrates at first this definition: "To bring a case against anyone who commits a crime (ezamartanti)... whether he happens to be a father or a mother or anyone else, and not to bring a case against them is unholy" (5d-e). The evidence for this comes, not only from the laws of the city, but from the gods, indeed the best and the most just of the gods, Zeus, who proceeded against his father for unjustly devouring his children (6a). Now, Euthyphro complains, men are angry at him for going against his father "and thus they say opposite things about the gods and about me" (6a). Apart from Euthyphro's assumption that the world is so ordered that the same rules apply to the gods and to himself, that the divine laws are identical to those inscribed on the stones around him, Euthyphro here is searching for a consistent standard, for uniformity of principles of actions for gods and for men, for son and for citizen. Again the particularity or difference between a man and a god, between a citizen and a stranger becomes irrelevant. ${ }^{23}$ Euthyphro functions under the impression that there is no complexity in piety. ${ }^{24} \mathrm{He}$ simply has to do what is right, and the city offers him the context within which he can apply his straightforward principles, uncluttered by the complexities introduced when one thinks of the multiplicity of relationships that arise as the result of one's existence as a member of a city as well as of a family, as one born not "from oak or stone."

Socrates' task here, I believe, ${ }^{25}$ is to force Euthyphro to understand complexity, to raise questions about attempts to impose abstract definitions and principles, ideas of right and wrong, just and unjust, pious and impious on a complex world. Euthyphro, at the beginning of the dialogue, is prepared to act against his father and his relatives for the sake of what is right, but he learns, under Socrates' guidance, that 
turning principle into practice is made difficult because of the various levels of one's existence - as a member of a household, a tribe, a city. He has not sprung from the earth, as do the inhabitants of Socrates' city in the Republic, those for whom there is no conflict between family and polis, nor can he be considered only a demesman or an Athenian. Thus Euthyphro exists on a multiplicity of planes, and definitions of justice may differ and change from one level to the next. The attempt to turn to the laws of the city is, in this case, the questionable use of the simple to deny the complex.

Indeed, we soon learn from Euthyphro's and Socrates' explorations that a definition of piety as that which is dear to the gods (theophiles) fails because, as Euthyphro admits early on, the gods themselves are at war with great hatreds (6b). They are, as is reiterated frequently, in conflict (stasiazousi, $7 \mathrm{~b}$ for the first reference). The term is a political one. The gods to whom Euthyphro turns for a consistent model of piety when humans themselves are inconsistent-even those gods fail him as he searches for precise principles. Thus he abstracts, trying to claim that there is no difference among the gods, that it is necessary to make him who unjustly kills someone pay the penalty (8b). Euthyphro tries to make as a statement of general principle that Cronos and Uranus would agree with Zeus and Euthyphro. ${ }^{26}$ But Socrates again draws Euthyphro onto the level of particulars. Give me proof, he asks, that the gods think it correct for a son to bring a case of murder against his father (9a). But Euthyphro relying on his general principles is certain that when someone knows - as he does - what is pleasing to the gods, to all the gods at all times, and acts according to that principle, he saves the private household and the community of the city; if he does otherwise and admits conflicts among values of gods as among the values of humans, if he admits the existence of stasis or factions, he destroys all (14b). Euthyphro claims that he will be able to convince the judges of this view, "if at least they listen to me speaking" $(9 b)$.

Euthyphro assumes an obviousness, a simplicity to the world, a world that he, though perhaps he alone, is able to comprehend. Socrates makes him see a world of gods and of men that is multifaceted and not uniform, a world in which context and not abstract principles must apply, a world in which gods as well as men differ. The family ties that Euthyphro was so eager to ignore at the beginning of his encounter with Socrates must be acknowledged. Athens is not Callipolis; the family has not been eliminated to make the city simple, uniform - and boring. Nor are the gods of the Greeks so simple or uniform, unchanging, and without conflict. 
The laws of the city seemed to allow Euthyphro to find abstract principles. The phrase "Let any man" begins the inscriptions on the stele at the Stoa Basileus. Euthyphro had come to the institutions of the city as a realm of universality, to escape the particularity of the family. Euthyphro thought that he was being pious by turning to those abstract principles that make the identity of the dead man and the murderer irrelevant for the pursuit of justice. Through Socrates' manipulation, that piety and that simple justice is questioned. The way to the truths of the gods is not through the city, with its attempt to focus on citizen over father or city over son. Perhaps by making piety an aspect of justice, as Socrates suggests in his final discourse with Euthyphro, Socrates is universalizing piety beyond Euthyphro, beyond the city, and indeed beyond the Greek gods. For the implications of such a move we would have to go beyond the Euthyphro at least to the Apology and Crito. The abstractions based on the city's democratic principles with which Euthyphro was working, Socrates shows us as well as Euthyphro, lead in circles to arguments that will walk away as do the statues of Daedalus. Euthyphro runs away at the end of the dialogue. Where to, we do not know. Indeed, we do not even know whether Euthyphro was on his way in or out of the Stoa. If Socrates' questions were successful, though, perhaps Euthyphro is returning to the complex world of multiple ties rather than the simple world of precise rules.

\section{EPILOGUE: MELETUS AND THE CITY'S DEFENSE OF THE UNIVERSAL}

The difference between Euthyphro and Socrates is indicated in the first lines of the dialogue in the difference between the graphé and diké. Euthyphro has come to the Stoa Basileus to use the laws of the city in a private matter; Socrates is there to be indicted by those eager to protect the city itself, to protect the laws and institutions of Athens from his corrupting influence. Euthyphro, the gossip that he is, upon hearing that Socrates is accused, wants to know who before what. Thus, before learning the nature of the charges against Socrates, we learn about the man with the name meaning care, concern, or attention to, this man who is young and unknown. ${ }^{27} \mathrm{We}$ are informed of his deme, Pittheus, which has replaced the older, aristocratic patronymic, suggesting for us the priority of his ties to his city over his ties to the family.

This Meletus, with his hooked nose and scraggily beard, recognized, according to Socrates, the importance of educating the young, but in his 
devotion to the city fails to understand the means of this education, means that Socrates, through his attention to the particular, has discovered. Describing the nature of Meletus' charges against him, Socrates notes that the charge itself is not ignoble. "For one so young, Meletus understands a matter not at all paltry" (2c). Indeed, Socrates even praises him: Alone of the citizens he begins properly. "Correctly, he is concerned first that the young be the best that is possible" (2d). Such concern can only lead to the greatest good for the city. The dripping irony of the passage is related to Meletus' youth and questionable knowledge, not to the principle of concern for making men as good as possible, a principle Socrates has often articulated as his goal.

Socrates continues to describe Meletus' intentions by introducing the image of the farmer concerned with the growth of young shoots before all else. The image draws forth no specific response from Euthyphrobut are the young of the city similar to the green shoots springing forth from the earth that the farmer tends, weeding out those bad shoots that are not up to the standards of the others? The seemingly reasonable image of the farmer draws us back to the Republic and to the traditional myths of autochthony at the basis of the Athenians' self-conception of their own origins; these are men sprung from the earth with neither father nor mother but, as citizens, related to one another by a common parentage in the earth itself. In such a world Euthyphro's prosecution of the murderer would be pious. The complexity imposed by a world in which he does have a father, a specific individual from whom he was born, raises questions about the piety of his deeds. In the world that abstracts from particular ties by setting all only in relation to the city and not the family, there can be no impiety. ${ }^{28}$ Euthyphro would not be subject to the kind of questioning that Socrates engages in here. In the Republic, according to the noble lie, the citizens of Socrates' city had sprung forth like shoots out of the earth-to ensure unity and devotion to their common mother. It is Meletus who now wishes to impose this vision of Callipolis on the city of Athens-not Socrates who in the Euthyphro wishes to explore the ties that bind one to particular individuals rather than to the abstractions of the democratic polity.

And yet we cannot ignore the fact that Socrates, the defender of piety toward one's father and the ties that arise within the family in the Euthyphro, leaves his own family in poverty and his children without a father to raise and educate them-all for service, as he puts it, to his god. Thrasymachus, in the Republic, well understands the threat that the pursuit of justice and virtue poses for the family of the just individual. As he says in Book I: "And when it is the turn for the just man to rule even if 
he suffers no other punishment, his household on account of a lack of care (ameleian) suffers hardships and from the people there is no benefit on account of his justice, and in addition to these things, his relatives and acquaintances are angry when he does not wish to serve them against what is just"(343e). Socrates as much as admits that in his speech before the court of the Athenians (Apology, 23c-d). Socrates, in response to Thrasymachus, had to eliminate the family, poverty and wealth, and private goods to found the just city. But the exigencies of the trial in 399 B.C. allow no opportunity to transform Athens into Callipolis and thus obviate the conflict between public and private. Socrates instead must show how his life-unique in the experience of Athens-accomplished what the institutions of the city cannot, a binding together of family and city that Meletus cannot comprehend. At the basis of this integration is Socrates' understanding of the piety that he and Euthyphro had with difficulty tried to define. It is a definition of piety particularly at odds with that offered by Meletus. Meletus is concerned with a piety grounded in the needs of the city, a city that he wants to see as whole, unified, and uniform, that is, a city like that in the Republic. ${ }^{29}$ The threat of new gods suggests cracks in the unity of the city-as does the presence of Socrates himself, the one corrupter among all the others who improve the young. In Meletus' city there is no room for loyalty to one's father, much less one's own god. There is no room for the particularity of a Socrates.

In the Apology, we find a Socrates who is concerned to point out how he is different from other men, how he values truth and virtue as the citizens of Athens do not, how he is not eager for political power, as the citizens of Athens are. The unique Socrates, this peculiar gift of the god, stands outside the democratic equality of the city. As such, he puts himself into the position not of participating with them on an equal basis in the assembly nor before the law, but paints himself almost as a father to the members of the city. We have to revise somewhat our image of Socrates giving his speech to the city: Instead of visualizing the old, stooped philosopher with receding forehead and bulging eyes, opposing the city, let us imagine Socrates as an old father scolding his childrenthe men of Athens whom he never dignifies by calling "judges" or "citizens." Socrates stands before the Athenians chastising them, not defending himself. ${ }^{30}$ In so doing he blurs the distinction between public and private, for, in becoming like a father to the citizens of Athens, he transforms the city into his family-and indeed his family into his city. $\mathrm{He}$ accomplishes this, not as in the Republic through fantastical myths and forced expulsions, but through individual action as private being, 
caring naught for wealth or power but for each individual. He speaks to all, "whether young or old . . . having wealth or not" (33a). His relationship to the citizens is not impartial interaction but personal care. Political life for him reflects the relationships of the family.

Socrates' explanation for his unique behavior depends in part on his claim to be given to the city by the gods. As evidence that he is such a gift, he refers to his inhuman lack of concern with his own affairs-that for so many years he has not attended to the affairs of his family - but always "attending to yours, going to each one of you in private (idia), just as a father or an older brother persuading you to be concerned with virtue" (31b). That he receives nothing for this effort-no drachma, no appreciation-is evidence that there is not any reason (tina logon) behind it (31b). Clearly, he comments, it is not part of human nature (ou gar anthropinoi) to act thusly, with no reason behind it. But is it not? Do not the analogies of the earlier part of the phrase belie the assertion? Do fathers or older brothers receive pay for their care of the young?

Indeed, in the earlier part of his speech, Socrates explicitly tells of fathers who pay enormous fees to others so that their sons will have the best teachers in virtue (19e-20a). Socrates' lack of care for his family is inhuman only if one separates family and city. Socrates has conflated them going to each citizen as though that citizen were a son or a younger brother. Socrates tries to introduce to the city ties that govern relations within the family-ties that Meletus from the deme of Pittheus and Euthyphro in his prosecution of his father choose to ignore in their adoration of the city and the abstract. Socrates, through his care for the education of the citizens as individuals, transforms the city from the abstract unity of equals to one made up of diverse citizens to whom he must go in private.

Socrates' life as a father draws him away, not from the city to the private world, but to the city as the expansion of that world where he, the philosopher, the exhorter to virtue, cares for the young as a father for his son. The city as an abstract unit with its laws engraved in stone tries to educate all at once and to punish according to its principles without attending to the peculiarity of each individual. Meletus has argued that Socrates corrupts the young. Who, Socrates wishes to know, makes them better? Meletus, taking the question to be what, responds: "The laws." Socrates is not satisfied with the abstract notion to which his accuser turns, for Meletus has referred not to a person (who) but to a concept (what), to the joint speech of citizens engraved on the inanimate stones of the Stoa Basileus. Socrates want to know: "What human being, tis anthropos, who first knows also this very thing, 
the laws" (24e). The laws do not act by themselves; they must be concretized in the body of an individual who can use, enforce, and educate according to them. Meletus, in his pursuit of abstract unity and perfection, had wanted to bypass the particular and the concrete. Socrates will not let him. Socrates thus puts him in the apparently absurd position of saying that everyone else but Socrates makes the young better, all, judges, listeners, council members, everyone except Socrates. ${ }^{31}$

However absurd Meletus' responses may seem, however much he may melt before Socrates'sharp intellect, Meletus is defending the unity of the community against the defiantly unique Socrates. For Meletus, there is no difference between a judge and the one who sits next to him. Athenian democracy is predicated on the interchangeability of each judge. The actual votes of the jury trying Socrates, or any assembly of men, suggests the fallibility of this view. Had the uniformity Meletus assumes to exist in the city actually existed, there would have been a unanimous vote for condemnation. Meletus is forced by Socrates to say that only Socrates is different, that only Socrates presents a threat to the unity of the city. We should see here the parallels with the Republic in the apparent desire to create a perfectly uniform city, only this time it is Socrates' accuser who argues for it. Meletus, able so quickly to forget the recent oligarchy, asserts the unity of the city, the absence of conflict that Socrates had forced Euthyphro to admit existed even among the gods. It is Meletus who wants to view the world as simple and whole, and especially the city within it, whereas Socrates sees them both as complex.

The problem with acknowledging differences and complexity plagues Meletus again when he fails to recognize the difference between Socrates and Anaxagoras. After Meletus insists that Socrates says that the sun is a stone and the moon earth, Socrates asks: "Do you think to accuse Anaxagoras, dear Meletus?"(26d). Meletus sees no difference between Socrates and Anaxagoras, between individuals or cases of impiety brought before the city. ${ }^{32}$ Again, concerning Socrates' beliefs in the gods, Meletus insists that Socrates believes in "no gods, none at all, by Zeus" (26e). But, as Socrates develops the argument against him, it becomes clear that Meletus' uniform perception of the atheistic Socrates must be modified by Socrates' belief in his daemon and in demigods, those complex creatures born of gods and humans. The belief in the gods is neither a clear yes nor a clear no, but a complex integration of the relation between actions and actors, children of the gods and their parents. 
Socrates refers specifically to his own sons in the third section of the Apology, in the last few words of his speech, when he asks of those who have condemned him to care for his children: "My sons, when they become young men, punish them, o men, causing them the same grief such as I caused you, if they seem to you to be concerned with either money or anything else other than virtue, and if they being nothing appear to be something, rebuke them just as I did to you-that they do not tend to those things they should tend to and that they think themselves, being nothing, to be worthy of something ... and if you do these things, I and my sons shall have had justice from you." ${ }_{33}$

It may seem surprising that Socrates asks those who have condemned him to care for his sons. But the justice referred to at the end of the passage indicates the parallel between Socrates' treatment of the city and the treatment he asks for his sons from the city. Justice will be accomplished when the city becomes a surrogate father to Socrates'sons as Socrates had been to the citizens of Athens. The transformation that Socrates, as a gift of the gods, had tried to accomplish in the city was based on his going from one to another-trying to make each one as good as possible, not treating them, as Meletus would, as young shoots to be tended and weeded through by a farmer, abstracted from the particularity of their growth and birth. Socrates' death will have been repaid and his sons receive justice should the city adopt for itself the same task of education that Socrates had practiced in the city of Athens. This is not the uniform education that Socrates had prescribed in the Republic but rather the education that comes from "going among you as a father or as an older brother." In condemning Socrates the Athenians have shown as little understanding of the meaning of piety, respect, and loyalty for those who have made one-or made one better, who have truly cared for one-as Euthyphro. The reaction we see on the part of the city arises from the desire to eliminate the one who acts against the principles of abstraction, who introduces particularities and differences, who raises questions about the principles of Athenian democracy. The justice of the city in repayment for the death of Socrates will be for the city itself to take over the role of Socrates, to act as Socrates with regard to the young and to learn the meaning of piety to the old. It is unclear whether Socrates expects this transformation to take place, indeed whether he expects that it can, but the story of the Crito explains why he must let the city try, why he supports the city when it did not support him, why, like Strepsiades, he continues to love his son though he causes him grief. ${ }^{34}$ 
Socrates as private being rather than public being (31c) sees each individual in his unique configuration and thus brings to the public the true care of the particular, as Euthyphro in his search for abstract principles of justice in the laws of the city and Meletus in his attempt to execute those laws cannot do. The education of Euthyphro thus prepares for the defense of Socrates, the philosopher who focuses on the particular against the city that portrays itself as universal, that in its drive to democratic equality before the law ignored the particular. In emphasizing here the city as universal and the philosopher as particular, I do not want to suggest that Socrates does not in many ways transcend the city for his own understanding of piety and justice; rather he differs from the city in his treatment of individuals whom the city universalizes through its laws and in his willingness to acknowledge both worlds, that of particularity and difference and that of abstraction, while in the dialogues discussed here, the city, Euthyphro, and Meletus are all faulted for their devotion only to the latter.

\section{NOTES}

1. Cf. Leo Strauss, Socrates and Aristophanes (Chicago: University of Chicago Press, 1966), esp. 43.

2. Cf. my earlier paper from which this article is drawn, "Family in the Last Days of Socrates"(Paper presented at the American Political Science Association Meetings, New Orleans, 1985).

3. Cf. Mary P. Nichols, "The Republic's Two Alternatives: Philosopher-Kings and Socrates," Political Theory (May 1984), 252-274.

4. Aristotle, The Constitution of Athens, 21.1-4.

5. Jean-Pierre Vernant, The Origins of Greek Thought (Ithaca, NY: Cornell University Press, 1982), 100-101.

6. Aristotle, The Constitution of Athens, $43 \mathrm{ff}$.

7. Vernant, The Origins of Greek Thought, 101.

8. Cf. my article, "Aeschylus' Oresteia: Misogyny, Philogyny, and Justice," Women and Politics (Summer 1984), 11-32.

9. See Carol Gilligan, In a Different Voice: Psychological Theory and Women's Development (Cambridge, MA: Harvard University Press, 1982); Nancy Chodorow, The Reproduction of Mothering: Psychoanalysis and the Sociology of Gender (Berkeley: University of California Press, 1978); Dorothy Dinnerstein. The Mermaid and the Minotaur: Sexual Arrangements and Human Malaise (New York: Harper and Row, 1976); and Sarah Ruddick, "Maternal Thinking," Feminist Studies (Summer 1980), 343-67.

10. The language here is from Gilligan, In a Different Voice, for example, 62.

11. For example, R. E. Allen, Plato's Euthyphro and the Earlier Theory of Forms (New York: Humanities Press, 1970). Cf. Jan Blitz, "The Holy and the Human: An 
Interpretation of Plato's Euthyphro," Apeiron (1980), 19 and especially the references in his $\mathrm{n} .2$.

12. Aristotle, The Constitution of Athens, 57.3

13. Aristotle, The Constitution of Athens, 57.3

14. Douglas M. MacDowell, The Law in Classical Athens (Ithaca: Cornell University Press, 1978), 46-47.

15. My main sources are as follows: Michael Gagarin, "The Prosecution of Homicide in Athens," Greek, Roman and Byzantine Studies (Winter 1979), 301-323; Gagarin, Drakon and Early Athenian Homicide Law (New Haven and London: Yale University Press, 1981); Morgen Herman Hansen, "The Prosecution of Homicide in Athens: A Reply," Greek, Roman and Byzantine Studies (Spring 1981), 11-30; MacDowell The Law in Classical Athens; and Douglas MacDowell, Athenian Homicide Law in the Age of the Orators (Manchester: University Press, 1963).

16. Cited in and trans. by Gagarin, Drakon and Early Athenian Homicide Law, xvi-xvii.

17. Gagarin, The Prosecution of Homicide, 303.

18. Hansen, "The Prosecution of Homicide," 13 and passim.

19. Robert J. Bonner and Gertrude Smith note that "it is possible that the early attitude towards homicide as the affair of the relatives persisted in the fifth and fourth century to such an extent that no legislation was ever passed which permitted the homicide to be dealt with directly by others than the relatives of the victim," in The Administration of Justice from Homer to Aristotle, vol. 2 (Chicago: University of Chicago Press, 1938), 210 .

20. Cf. Marlo Lewis, “An Interpretation of Plato's Euthyphro (Introduction; pt. 1, sec. 1-3)," Interpretation (May and September 1984), 225-259.

21. Gagarin, Drakon and Early Athenian Homicide Law, 164.

22. MacDowell, Athenian Homicide Law, 11, explains: "The rules of religion... were not established; knowledge of them was a pre-rogative of the exegetai ('expounders'), and in the cases of doubt these officials had to be consulted."

23. Lewis, "An Interpretation of Plato's Euthyphro," 253, phrases the problem in somewhat similar terms: "Euthyphro's zeal for diké ... or interfamilial justice has all but obliterated his concern for themis or justice within the family group.... there is obviously a tension between loyalty to one's own and the principle of fair and equal treatment for all. Euthyphro's action can in part be understood as a working out of the 'logic' of impartial justice."

24. Or we should note that Socrates pushes him in the direction of admitting this: "Did you say that by one idea the unholy things are unholy and the holy things are holy?"(6d-e). Socrates helps him to articulate the perspective that underlies his decision to prosecute his father.

25. I admit that I am arguing here against the preponderance of scholarly work on the dialogue; cf., e.g., Harry Neumann, "The Problem of Piety in Plato's Euthyphro," The Modern Schoolman (March 1966) 265-72, for one of the better expositions from the opposite perspective.

26. We should remember here that one of the aims of Books II and III of the Republic is the transformation of the gods into one god so that there can be no conflict between them. To do this, Socrates makes them uniform, multiplicity being denied among the gods as it is among the rulers of the city.

27. He is thus rather like Euthyphro who is young and at least sufficiently unknown 
for the Athenians not to bother to bring him to trial for the impieties he is eager to teach $(3 b-c)$.

28. Politics, II.4. Here it is important to consider the criticism that Aristotle makes of Socrates' proposals for the destruction of the family in the Republic, in particular that they will allow for the grossest kinds of impiety.

29. It is unclear what the law against impiety entailed. In 403-402 B.C., a law was passed that no uninscribed law was to be enforced, but no law specifying what impiety was remains. MacDowell, Law in Classical Athens, p. 199, speculates that the law probably went: "If anyone commits impiety, let anyone who wishes submit a graphé without offering any definition of impiety."

30. Eva Brann, "The Offense of Socrates: A Re-reading of Plato's Apology," Interpretation (May 1978), 1-21.

31. Socrates' refusal to accept laws as acting without the particularity of individual enforcers must, of course, be contrasted to the willingness to talk to the abstract laws of the Crito and thus alert us to the different texture and aims of the two dialogues.

32. MacDowell, The Law in Classical Athens, 200-201, suggests that the law according to which Anaxagoras was perhaps prosecuted lapsed in the rewriting of the laws in 403 B.C., especially since the procedures for a trial of impiety differed substantially between the two cases.

33. Leo Strauss, Platonic Political Philosophy (Chicago: University of Chicago Press, 1983), 54, comments extensively on this particular passage in his essay on the Apology and Crito: "What may cause some wonder is that he entrusts to them, and not to the acquitters who he describes as his friends, the concern with the virtue of his sons. . . he seems to expect his condemners and accusers to become spiritual heirs at least as far as his sons are concerned. Yet, by entrusting his sons to his condemners he entrusts them to the majority, i.e., to the city; and the city is concerned with virtue, if only with vulgar virtue; it can be expected to urge Socrates's sons to that kind of virtue."

34. I suggest here only that in the Crito we see Socrates as son to the city as father. Cf. the paper cited above in $n .2$.

Arlene W. Saxonhouse is Professor of Political Science at the University of Michigan. Her interests are primarily in the area of classical political thought. Her recent publications include Women in the History of Political Thought: Ancient Greece to Machiavelli (Praeger, 1985) and "From Tragedy to Hierarchy and Back Again: Women in Greek Political Thought"(American Political Science Review, June 1986). 